\title{
Analisis Motivasi Siswa dalam Mengerjakan Tugas Rumah Di SMA Al- Mannan Tolitoli
}

\author{
Moh. Rudini ${ }^{1}$, Ade Agustina ${ }^{2}$ \\ ${ }^{1,2}$ Program Studi Teknologi pendidikan, Universitas Madako Tolitoli \\ JL. Umada No. 1 Tolitoli, Indonesia \\ muhammadrudini87@gmail.com
}

\begin{abstract}
This research is motivated by the low motivation of students in doing homework at Al-Mannan High School, where motivation is the basis of encouraging students to be enthusiastic in learning. This study uses descriptive qualitative methods, namely research that reveals events or facts that are in accordance with what happened in the field where the researcher is the main key in its implementation and uses data collection techniques from observation, interviews and documentation. Based on the results of the data research, it shows that the analysis of student motivation in doing homework at Al-Mannan High School is not motivated, this is seen from the first indicator they are willing to try and try even though they repeatedly fail that students are indifferent to giving homework. The second indicator is doing homework early, students rarely do homework, students do homework only when they have free time. The third indicator is active when learning shows students are less active in responding to teachers so that there is less feedback between students and teachers in the classroom, students pay less attention. The fourth indicator is on time in collecting homework, students are less disciplined in collecting assignments because students prioritize assignments from the cottage. The inhibiting factor for students' motivation in doing homework is the busy cottage activities that make it difficult for students to divide their time by doing homework.
\end{abstract}

Keywords: Analysis, Motivation, Homework.

\begin{abstract}
Abstrak
Penelitian ini dilatar belakangi oleh motivasi siswa dalam mengerjakan tugas rumah di SMA Al-Mannan yang rendah, dimana motivasi adalah merupakan dasar pendorong siswa untuk semangat dalam belajar. penelitian ini menggunakan metode kualitatif deskriptif yaitu penelitian yang mengungkap kejadian atau fakta yang sesuai dengan yang terjadi dilapangan dimana peneliti menjadi kunci utama dalam pelaksanaanya dan menggunakan teknik pengambilan data dari observasi, wawancara dan dokumentasi. Berdasarkan hasil penelitian data menunjukkan bahwa analisis motivasi siswa dalam mengerjakan tugas rumah di SMA Al-Mannan tidak termotivasi, ini dilihat dari indikator pertama mau mencoba dan mencoba meskipun berulangkali gagal bahwa siswa acuh dengan adanya pemberian tugas rumah. indikator kedua lebih awal mengerjakan tugas rumah siswa jarang sekali mengerjakan PR, siswa mengerjakan PR hanya pada saat memiliki waktu yang luang. Indikator ketiga aktif pada saat pembelajaran menunjukkan siswa kurang aktif dalam merespon guru sehingga kurang adanya feedback antara siswa dan guru di dalam kelas, siswa kurang memperhatikan. Indikator keempat tepat waktu dalam mengumpulkan tugas rumah, siswa kurang disiplin dalam mengumpulkan tugas karena siswa mendahulukan tugas dari pondok. Faktor penghambat motivasi siswa dalam mengerjakan tugas rumah adalah kegiatan pondok yang padat sehingga menyulitkan siswa dalam membagi waktu dengan mengerjakan tugas rumah.
\end{abstract}

Kata kunci: Analisis, Motivasi, Tugas rumah.

Copyright (c) 2021 Moh. Rudini, Ade Agustina

$\triangle$ Corresponding author: Moh. Rudini

Email Address: muhammadrudini87@gmail.com (JL. Umada No. 1 Tolitoli, Indonesia)

Received 30 Januari 2021, Accepted 26 Februari 2021, Published 27 Maret 2021

\section{PENDAHULUAN}

Keberhasilan belajar peserta didik dalam proses pembelajaran sangat dipengaruhi oleh motivasi yang ada pada dirinya. Indikator kualitas pembelajaran salah satunya adalah adanya motivasi yang tinggi dari para peserta didik. Peserta didikyang memiliki motivasi belajar yang tinggi terhadap pembelajaran maka mereka akan tergerak atau tergugah untuk memiliki keinginan melakukan sesuatu yang dapat memperoleh hasil atau tujuan tertentu Hal ini sejalan dengan yang disebutkan dalam Undang-Undang Sistim Pendidikan Nasional bahwa "Pendidikan adalah usaha sadar dan terencana untuk mewujudkan 
suasana belajar dan proses pembelajaran agar peserta didik secara aktif mengembangkan potensi dirinya untuk memiliki kekuatan spiritual keagamaan, pengendalian diri, kepribadian, kecerdasan, akhlak mulia, serta ketrampilan yang diperlukan dirinya masyarakat bangsa dan negara" (Pasal 1 UU RI No.20 th.2003). Menurut (Iskandar, 2018) Guru merupakan elemen kunci dalam system Pendidikan, khususnya di sekolah. Semua komponenlain, mulai dari kurikulum, sarana prasarana, biaya, dan sebagainya tidak akan banyak berarti apabila esensi pembelajaran yaitu interaksi guru dan siswa tidak berkualitas.

Pendapat di atas mengandung pengertian bahwa pendidikan adalah proses mengembangkan kemampuan, bakat dan potensi peserta didik agar berkembang aspek- aspek kognitif, sosial dan spiritualnya. Berbicara masalah peserta didik maka erat kaitannya dengan prestasi dan motivasi belajar, sebab motivasi belajar yang tinggi pengaruhnya akan sangat besar terhadap capaian hasil belajar atau prestasi belajar. Dalam belajar sangat diperlukan adanya motivasi. "Motivation is an essential condition of learning”. Hasil belajar akan optimal jika ada motivasi dari peserta didik. Motivasi yang akan menentukan intensitas, gairah dan usaha belajar yang dilakukan peserta didik. Menurut (Iv \& Gondosuli, 2020)siswa yang mempunyai disiplin dan motivasi belajar yang tinggi akan mempunyai keinginan dan melakukan kegiatan belajar lebih tekun untuk mencapai prestasi belajar yang diharapkan.

Menurut Mudjiono (Andriani, 2019) mengatakan motivasi dipandang sebagai dorongan mental yang menggerakkan dan mengarahkan perilaku manusia termasuk perilaku belajar. Dalam motivasi terkandung adanya keinginan, harapan, tujuan, sasaran, dan insentif dimana keadaan inilah yang yang mengaktifkan, menggerakkan, menyalurkan dan mengarahkan sikap dan perilaku individu belajar. Peserta didik yang mempunyai motivasi yang kuat akan memiliki energi untuk belajar yang banyak. Mereka akan semangat dan senang untuk belajar. Motivasi juga akan menjadi pendorong dalam pencapaian prestasi. Karena mempunyai peranan penting yang strategis dalam aktivitas belajara seseorang. Seseorang melakukan aktivitas belajar karena ada yang mendorongnya, motivasilah sebagai dasar penggeraknya yang mendorong seseorang untuk belajar.

Menurut Hamalik (Iv \& Gondosuli, 2020) menyatakan bahwa pembelajaran yang efektif adalah pembelajaran yang menyediakan kesempatan belajar sendiri atau melakukan aktivitas seluas-luasnya kepada siswa untuk belajar terutama pada saat memberikan pekerjaan rumah pengaruh seorang guru memang besar, anak-anak pada umumnya menghargai seorang guru apa bila guru itu senang pada anakanak. Yang mengajar harus mulai mencari dan menarik minat dan perhatian, dan jangan mengira bahwa yang diminati guru akan diminati oleh anak-anak. Sering kali, hanya merupakan suatu kebetulan kalau guru dan murid langsung cocok, salah satu bentuk kemitraan antara sekolah dan keluarga dapat berupa pemberian pekerjaan rumah dari guru.

Menurut (Saragih et al., 2019), tugas rumah (PR) dalam pembelajaran yakni metode penugasan yaitu penyajian bahan dimana guru memberikan tugas tertentu agar siswa melakukan kegiatan belajar, masalahnya tugas yang diberikan dapat dikerjakan dirumah atau dimana saja tugas itu dapat dikerjakan. 
Metode ini diberikan karena dirasakan bahan pelajaran terlalu banyak, sementara waktu sedikit. Artinya, banyak bahan yang tersedia namun waktu yang kurang seimbang.

Pemberian pekerjaan rumah (Prihatini, 2018) merupakan metode mengajar yang diberikan guru kepada siswanya dengan tujuan membiasakan dan merangsang siswa tekun, rajin, ulet dan giat belajar terutama belajar di rumah. Dengan sisi lain pemberian pekerjaan rumah kepada siswa juga memberikan kesempatan untuk mendapatkan pengalaman yang lebih banyak agar kepribadian dan penalarannya berkembang. Menurut (Darmawan et al., 2017) dengan pemberian tugas berarti pula menganggap siswa bukan hanya sebagai objek pendidikan tetapi juga sebagai subjek pendidikan yang harus mencari dan menyelesaikan permasalahan yang dihadapinya di bawah bimbingan dan pengarahan guru. Pusat kegiatan pemberian pekerjaan rumah berada pada siswa dan mereka disajikan bermacam-macam masalah agar mereka menyelesaikan, menanggapi dan memikirkan masalah tersebut. Yang penting bagaimana melatih siswa agar berfikir bebas ilmiah (logis dan sistematis) mempertanggung jawabkannya.

Menurut (Awe \& Benge, 2017) motivasi belajar dibutuhkan dalam proses pencapaian prestasi. Siswa yang tidak mempunyai motivasi belajar akan kekurangan semangat belajar sehingga berdampak pada prestasinya menurun. Berdasarkan hasil dari pra penelitian yang peneliti lakukan di SMA AlMannan, masih ditemukan banyak peserta didik yang motivasi belajarnya rendah, hal ini sejalan dengan adanya sikap yang ditunjukkan peserta didik saat kegiatan belajar dan mengajar berlangsung yaitu : masih terdapatnya siswa yang masih melalaikan pekerjaan rumah yang diberikan oleh guru, siswa yang tidak mengerjakan latihan yang diberikan oleh guru, siswa yang mengobrol saat guru sedang menjelaskan materi pelejaran, dan siswa yang hanya belajar saat akan ada ulangan. Rendahnya motivasi belajar siswa dipengaruhi karena faktor ekstrinsik maupun intrinsik. Faktor ekstrinsik adalah dorongan untuk belajar yang berasal dari luar siswa, sedangkan faktor intrinsik adalah dorongan untuk belajar yang berasal dari dalam dirinya sendiri.

Berdasarkan obsevasi awal di SMA Al-Mannan, dapat terlihat bahwa cara mengajar yang diterapkan masih bersifat konvensional (ceramah) membuat siswa kurang bersemangat dan kurang termotivasi dalam belajar dan mudah bosan dalam mengikuti pelajaran, di SMA Al-Mannan juga masih kurang dalam hal sarana dan prasana pembelajaran sehingga siswa terbatas dalam menemukan sumbersumber pelajaran yang menyebabkan siswa kesulitan dalam mengerjakan tugas rumah yang diberikan guru karena mengingat di SMA Al-Mannan siswa di wajibkan untuk mondok, dan juga dikarenakan kegiatan mondok yang padat yang mengharuskan siswa sulit membagi waktu dengan kepentingan sekolah yaitu salah satunya pekerjaan rumah (PR) selain itu pemberian pekerjaan rumah diberitahukan setelah bel berbunyi sehingga perhatian para siswa sudah tidak ada, khususnya dalam mengerjakan pekerjaan rumah (PR) yang diberikan oleh guru di sekolah, Padahal dengan adanya pekerjaan rumah, siswa dapat mengingat dan mengulangi pelajaran yang diberikan di sekolah. Inilah kenyataanya yang terjadi di SMA Al-Mannan sehingga penulis tertarik untuk meneliti mengenai “Analisis Motivasi Siswa Dalam Mengerjakan Tugas Rumah Di SMA Al-Mannan Tolitoli’’. 
Adapun rumusan masalah pada penelitian ini yaitu bagaimana motivasi siswa dalam mengerjakan tugas rumah di SMA Al-Mannan dan Apa faktor penghambat motivasi siswa kelas X dalam mengerjakan tugas rumah di SMA Al-Mannan Tolitoli. Penelitian ini bertujuan untuk menganalisis motivasi siswa kelas $\mathrm{X}$ dalam mengerjakan tugas rumah dan untuk mengetahui faktor pengehambat dan pendukung siswa dalam mengerjakan tugas rumah di SMA Al-Mannan Tolitoli.

Menurut (Zainal, 2018) mengatakan motivasi adalah serangkaian usaha untuk menyediakan kondisi atau keadaan tertentu, sehingga seseorang mau dan ingin melakukan sesuatu dan bila tidak suka maka akan berusaha untuk meniadakan atau mengelakkan perasaan tidak suka itu. Jadi motivasi dapat diransang oleh faktor dari luar, tetapi motivasi itu tumbuh di dalam diri seseorang, lingkungan merupakan salah satu faktor dari luar yang dapat menumbuhkan motivasi dalam diri seseorang untuk belajar. Sedangkan menurut (Ernata, 2017) Motivasi juga dapat diartikan sebagai suatu keadaan internal organisme baik manusia ataupun hewan yang mendorongnya untuk berbuat sesuatu. Dalam pengertian ini, Motivasi berarti pemasok daya (energizer) untuk bertingakah laku secara tterarah.

Menurut Sardiman (Sitti, 2015) menyebutkan Fungsi motivasi adalah sebagai berikut:

1. Mendorong manusia untuk melakukan, sebagai motor penggerak siswa untuk melakukan kegiatan. Dengan kata lain motivasi dapat diartikan sebagai suatu dorongan dari dalam diri ataupun dari luar diri siswa untuk melakukan sesuatu tanpa adanya paksaan.

2. Menentukan arah perbuatan, dengan motivasi dapat memberi arah yang harus dikerjakan sehingga siswa tau apa yang harus dilakukan.

3. Menyeleksi perbuatan, dalam hal ini yakni mmenentukan perbuatan-perbuatan apa yang harus dikerjakan yang serasi guna mencapai tujuan

Berbicara tentang macam atau jenis motivasi dapat dilihat dari berbagai sudut pandang, menurut (Wulansari, 2020), motivasi dibedakan menjadi 3 macam menurut sifatnya: Motivasi takut atau fear motivation, yakni individu melakukan suatu perbuata n dikarenakan adanya rasa takut. Dalam hal ini seseorang melakukan suatu perbuatan dikarenakan adanya rasa takut, misalnya takut karena ancaman dari luar, takut akan mendapatkan hukuman dan sebagainya. Motivasi intensif atau incentive motivation, yaitu individu melakukan sesuatu perbuatan untuk mendapatkan insentif, bentuk insentif bermacammacam seperti mendapatkan honorarium, bonus, hadiah, penghargaan, dan lain-lain. Motivasi sikap atau attitude motivation self, motivasi sikap (Sari \& Sunarno, 2018) merupakan suatu motivasi karena menunjukkan ketertarikan dan ketidak tertarikan seseorang terhadap suatu objek, motivasi ini lebih bersifat intrinsic, muncul dari dalam individu, berbeda dengan kedua motivasi sebelumnya yang lebih bersifat ekstrinsik yang datang dari luar diri seseorang.

Motivasi belajar siswa dapat diukur menggunakan instrumen yang dikembangkan berdasarkan aspek-aspek dari motivasi belajar. Menurut Keller (Emda, 2018), mengembangkan aspek-aspek yang dapat digunakan untuk mengukur tingkat motivasi belajar siswa yang dinamakan ARCS di dasarkan pada sintetis dari konsep motivasi dan karakteristik motivasi yang dikelompokkan menjadi 4 bagian, yakni: 
1. Perhatian (Attention), yaitu sikap yang ditunjukkan oleh siswa dengan memberi atensi atau pemfokusan diri terhadap pelajaran dimana perhatian siswa tersebut timbul karena faktor rasa ingin tau.

2. Relevansi (Relevance), yaitu pandangan siswa tentang keterkaitan antara manfaat dan aplikasinya dengan kehidupan sehari-hari. Motivasi belajar siswa akan terjaga apabila siswa dapat menemukan hubungan antara apa yang dipelajari dengan manfaatnya dalam memenuhi kebutuhan pribadi maupun sesuia dengan nilai yang diyakini.

3. Percaya diri (confidence), adalah keyakinan diri siswa dalam belajar dan menyelesaikan masalah. Siswa yang memiliki rasa bahwa dirinya berkompeten atau mampu dalam belajar, maka keinginan untuk belajar semakin baik.

4. Kepuasan (satisfaction), yakni rasa puas dalam diri siswa dalam memecahkan permasalahan yang sedang dipelajari.

Menurut (Sari \& Sunarno, 2018), untuk mengetahui kekuatan motivasi belajar siswa dapat dilihat dari beberapa indikator sebagai berikut:

1. Mau mencoba dan mencoba meskipun berulangkali gagal, siswa dalam pembelajaran tentunya memiliki rasa bosan dalam mengerjakan tugas, apalagi siswa dibebani dengan tugas-tugas lainnya di pesantren. Ini membuat siswa menjadi malas dan tidak terdoromg untuk mengerjakan tugas rumah (PR). Inilah pentingnya memotivasi siswa dalam memberikan semangat kepada siswa agar mau mencoba dan terus mencoba meskipun berulang kali gagal dalam setiap mengerjakan tugas yang diberikan oleh guru.

2. Lebih awal untuk mengerjakan tugas atau PR yang telah diberikan, siswa yang memiliki kemauan akan terlihat ketika usaha yang dilakukan menjadikan siswa selalu tergerak untuk bergerak cepat, mengerjakan tugas/PR lebih awal, dan selalu memprioritaskan tugas/PR ketimbang bermain dengan teman sebayanya.

3. Aktif pada saat pembelajaran, adanya feedback di dalam kelas antara guru dan siswa ataupun siswa dengan siswa yang lain meunjukkan adanya rasa ingin tau yang tinggi dari siswa, keaktifan tersebut termaksud tanda keberhasilan didalam proses pembelajaran.

4. Tepat waktu dalam mengumpulkan tugas yang di berikan guru, apabila di dalam diri siswa terdapat sikap disiplin dan bertanggung jawab terhadap tugas atau PR yang guru berikan guru maka siswa akan selalu menjadi yang terdepan, berusaha selalu menjadi yang pertama dan tepat waktu dalam hal apapun karena siswa tersebut termotivasi dengan merasa seperti berkompetisi dan berlomba guna mendapatkan nilai yang terbaik.

Berdasarkan konsep yang disampaikan oleh (Darmawan et al., 2017) mengatakan bahwa tugas rumah banyak memberikan manfaat diantaranya yaitu: (1) memperbolehkan siswa berlatih, melanjutkan dan memperkuat materi yang diterima di dalam kelas, (2) mengajar siswa bagaimana merencanakan dan mengatur waktu, (3) memantapkan kebiasaan belajar, konsentrasi dan disiplin diri. 
Menurut (Murapi et al., 2020) Upaya yang dilakukan guru guna mengefektifkan pemberian tugas rumah (PR) dapat di uraikan sebagai berikut:

1. Tugas yang diberikan mempunyai pertalian erat dengan bahan yang telah di ajarkan di kelas

2. Usahakan tugas yang diberikan disadari benar manfaatnya oleh siswa guna menimbulkan minat yang lebih besar

3. Waktu yang diberikan untuk melaksanakan tugas tidak terlalu lama atau pendek agar tidak menimbulkan kejemuan atau kecemasan

4. Upayakan agar siswa tau tentang alat dan cara menilai hasil PR tersebut sehingga akan mengurangi banyaknya kesalahan dan rendahnya nilai

5. Guru tidak sungkan memberikan hadiah kepada mereka yang berhasil serta hukuman kepada mereka yang mengerjakan dengan konsekuen.

Menurut Sabri (Damayanti, 2017) menyatakan bahwa pemberian tugas rumah merupakan suatu metode pembelajaran yang diharapkan dapat meningkatkan hasil belajar siswa, karena dengan pemberian tugas rumah dapat merangsang dan memotivasi siswa untuk belajar, mendorong siswa untuk mencari dan mengolah sendiri tugas yang diberikan. Disamping itumemberikan kesempatan kepada siswa dalam mengembangkan kemampuannya dalam berfikir kreatif yang selanjutnya diharapkan dapat meningkatkan kemampuan siswa dalam proses belajarnya.

\section{METODE}

Jenis penelitian ini adalah penelitian kualitatif. Penelitian ini dilaksanakan untuk menganalisis motivasi siswa dalam mengerjakan tugas rumah di SMA Al-Mannan, Menurut Sugiyono (2015:15), metode penelitian kualitatif adalah metode penelitian yang berlandaskan pada filsafat post positivisme, digunakan untuk meneliti pada kondisi obyek yang alamiah, (sebagai lawannya eksperimen) dimana peneliti adalah sebagai instrumen kunci, pengambilan sampel sumber data dilakukan secara purposive dan snowball, teknik pengumpulan dengan tri-anggulasi (gabungan), analisis data bersifat induktif kualitatif, dan hasil penelitian kualitatif lebih menekakankan makna dari pada generalisasi.

Penelitian ini dilaksanakan di SMA Al-Mannan yang terletak di Jl. Dapalak, Kecamatan Baolan. Waktu penelitian dilaksanakan pada bulan Juni sampai dengan bulan Agustus 2020. Subjek penelitian adalah individu yang dijadikan sumber informasi yang dibutuhkan keterangannya dalam pengumpulan data penelitian. Dikalangan peneliti kualitatif, istilah responden atau subjek penelitian disebut dengan informan, yaitu orang yang memberi informasi tentang data yang di inginkan peneliti berkaitan dengan penelitian yang sedang dilakukan. Adapun subjek dalam penelitian ini yakni 2 orang guru di kelas $\mathrm{X}$ dan 3 orang siswa kelas X SMA Al-Mannan.

Penelitian ini menggunakan teknik pengumpulan data berupa pedoman wawancara, pedoman observasi, dan dokumentasi yang di ambil selama melakukan penelitian dilapangan. Teknik analisis data yang digunakan adalah reduksi data, penyajian data, dan kesimpulan atau verifikasi. Penerapan teknik analisa deskriptif dilakukan melalui 3 alur kegiatan, yaitu: 


\section{Reduksi Data}

Reduksi data adalah merupakan proses pemilihan, pemusatan perhatian pada penyederhanaan, pengabstrakan, tranformasi data kasar, yang muncul dari data catatan-catatan lapangan. Reduksi data berlangsung terus-menerus selama penelitian berlangsung. Reduksi adalah salah satu bentuk analisis yang menajamkan dan menggolongkan, mengarahkan, membuang yang tidak perlu dan mengorganisasikan data sedemikian rupa sehingga kesimpulan akhirnya dapat ditarik dan diverifikasi. Mereduksi data berarti merangkum, memilih hal-hal yang pokok, memfokuskan pada hal-hal yang penting, serta mencari tema dan polanya. Dengan demikian data yang telah di reduksi akan memberikan gambaran yang jelas, dan mempermudah peneliti untuk melakukan pengumpulan data selanjutnya, dan mencarinya bila diperlukan. Peneliti perlu memilah antara data-data yang fokus mengenai implementasi program pendidikan inklusif dan prestasi belajar siswa inklusi.

\section{Penyajian Data}

Setelah data direduksi, maka langkah selanjutnya adalah mendisplaykan data. Dalam penelitian kualitatif, penyajian data bisa dilakukan dalam bentuk uraian singkat, bagan, hubungan antar kategori, flowchart, dan sejenisnya. Yang paling sering digunakan untuk menyajikan data dalam penelitian kualitatif adalah dengan teks yang bersifat naratif. Penyajian data adalah penyusunan informasi yang kompleks ke dalam suatu bentuk yang sistematis, sehingga menjadi lebih selektif dan sederhana, serta memberikan kemungkinan adanya penarikan kesimpulan data dan pengambilan tindakan.

\section{Kesimpulan atau Verifikasi}

Kegiatan selanjutnya adalah menarik kesimpulan atau verifikasi. Dalam kegiatan verifikasi ini peneliti melaksanakan dengan cara mencari pola, model, tema, hubungan, persamaan, hal-hal yang sering muncul, hipotesis, dan sebagainya. Jadi dari data yang diperoleh peneliti berusaha mengambil kesimpulan. Peneliti akan menangani kesimpulan-kesimpulan itu dengan longgar, tetap terbuka, dan skeptis, tetapi kesimpulan sudah disediakan awal mula belum jelas kemudian menjadi lebih rinci dan mengakar dengan kokoh. Kesimpulan-kesimpulan akhir mungkin tidak muncul sampai pengumpulan data terakhir, tergantung besarnya kumpulan-kumpulan catatan lapangan, pengkodeannya, penyimpanan dan metode pencarian ulang yang digunakan, kecakapan peneliti dan tuntutan - tuntutan pemberian data. Tetapi seringkali kesimpulan itu telah dirumuskan sejak awal. Sehingga pada tahap akhir, kesimpulan-kesimpulan ini harus diverifikasikan pada catatan-catatan yang dibuatoleh peneliti yang selanjutnya disusun menjadi kesimpulan yang benar-benar matang. Adapun bagan alur analisis datapenelitian ini dapat digambarkan pada bagan alir 1. 


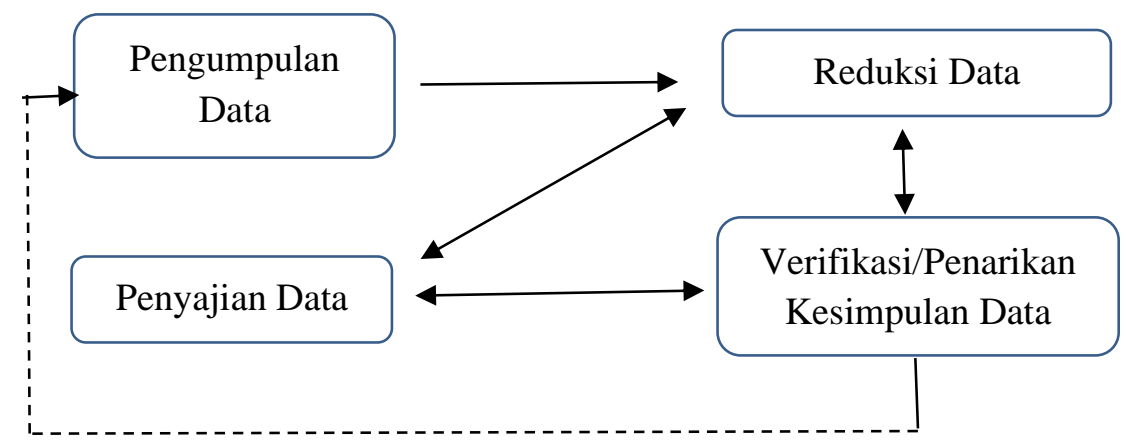

Bagan 1. Alur Analisis Data Penelian

\section{HASIL DAN DISKUSI}

Berdasarkan hasil penelitian yang ditemukan di SMA Al-Mannan yang dianalisis dari data hasil wawancara, dokumentasi dan diperkuat oleh data dokumentasi, Motivasi siswa dalam mengerjakan tugas rumah dari 4 indikator dapat disajikan data sebagai berikut:

1. Mencoba dan Mencoba Meskipun berulangkali Gagal, berdasarkan hasil wawancara dan observasi yang dilakukan peneliti, berdasarkan keterangan dan informasi dari subjek didapatkan keterangan bahwa siswa dalam usaha mau mencoba dan mencoba meskipun berulangkali gagal, siswa acuh dan cuek dengan adanya PR apalagi dengan adanya remedial guna memperbaiki nilai mereka yang kurang, siswa pun hanya sebagian kecilnya saja yang semangat untuk bertanya pada guru terkait tugas-tugas ataupun PR bahkan terkadang lupa dengan adanya PR pada kasus ini yang cenderung aktif yakni guru yang terkadang mengingatkan dan memberi saran untuk diadakannya remedial agar siswa mendapatkan nilai yang baik.

2. Lebih Awal Mengerjakan tugas atau PR bahwa siswa dalam usaha lebih awal mengerjakan PR yaitu siswa mengerjakan PR hanya pada saat memiliki waktu yang luang, waktu dimana siswa tidak lagi melakukan kegiatan-kegiatan di pondok, waktu istirahat siswa hanya pada waktu setelah sholat dzuhur sampai setelah sholat ashar dan hanya pada saat jam 10 malam yakni jam tidur malam bagi siswa hal tersebut juga membuat siswa cepat kelelahan sehingga terkadang siswa mengenyampingkan tugas PR dan memilih untuk istirahat, hal ini menyebabkan siswa menjadi cuek dengan PR dan kurang disiplin dengan waktu pengumpulannya, akhirnya tergesah-gesah membuat hasil PR-nya pun tidak sesuai dengan harapan.

3. Aktif Pada saat pembelajaran bahwa siswa dalam usaha aktif pada saat pembelajaran yaitu siswa kurang aktif dalam merespon guru sehingga kurang sekali terjadi adanya feedback antara siswa dan guru di dalam kelas, siswa kurang memperhatikan dan kurang fokus karena terkadang siswa kecapean yang membuat siswa mudah mengantuk sehingga tidak jarang catatan milik mereka tidak lengkap dan lupa akan adanya PR. Sejalan dengan data tersebut hal ini sejalan dengan apa yang disampaikan oleh (Yuliani, 2013) yang mengatakan bahwa siswa yang motivasi belajarnya lemah, dalam proses pembelajaran akan tampak acuh tak acu, mudah putus asa, perhatiannya tidak tertuju 
pada pelajaran, suka mengganggu kelas, sering meninggalkan pelajaran akibatnya banyak mengalami kesulitan belajar.

4. Tepat Waktu dalam mengumpukan Tugas atau PR dalam ketepatan waktu pengumpulan tugas PR, siswa kurang disiplin dalam mengumpulkan tugas sesuai waktu yang diberikan guru karena siswa sering kewalahan dalam membagi mengerjakan tugas sekolah dan melakukan kegiatan di pondok. Apabila di dalam diri siswa terdapat sikap disiplin dan bertanggung jawab terhadap tugas atau PR yang guru berikan guru maka siswa akan selalu menjadi yang terdepan, berusaha selalu menjadi yang pertama dan tepat waktu dalam hal apapun karena siswa tersebut termotivasi dengan merasa seperti berkompetisi dan berlomba guna mendapatkan nilai yang terbaik.

Berdasarkan indikator yang ditetapkan sebagai dasar analisis motivasi siswa dalam mengerjakan tugas rumah (PR) siswa di SMA Al-Mannan Tolitoli menunjukkan tidak termotivasi. Ini terlihat dari indicator satu sampai empat menunjukkan hasil yang kurang efektif dan tidak termotivasi. Seeuai dengan penelitian terdahulu yang telah dilaksanakan oleh beberapa peneliti sebelumnya telah mengemukakan bahwa mengembangkan aspek-aspek yang dapat digunakan untuk mengukur tingkat motivasi belajar siswa salah satunya yang dinamakan ARCS didasarkan pada sintetis dari konsep motivasi dan karakteristik motivasi yang dikelompokkan menjadi empat bagian, yakni perhatian (Attention), yaitu sikap yang ditunjukkan oleh siswa dengan memberi atensi atau pemfokusan diri terhadap pelajaran dimana perhatian siswa tersebut timbul karena faktor rasa ingin tahu. Relevansi (Relevance), yaitu pandangan siswa tentang keterkaitan antara manfaat dan aplikasinya dengan kehidupan sehari-hari. Motivasi belajar siswa akan terjaga apabila siswa dapat menemukan hubungan antara apa yang dipelajari dengan manfaatnya dalam memenuhi kebutuhan pribadi maupun sesuai dengan nilai yang diyakini. Selanjutnya adalah Percaya diri (confidence), adalah keyakinan diri siswa dalam belajar dan menyelesaikan masalah. Siswa yang memiliki rasa bahwa dirinya berkompeten atau mampu dalam belajar, maka keinginan untuk belajar semakin baik. Kepuasan (satisfaction), yakni rasa puas dalam diri siswa dalam memecahkan permasalahan yang sedang dipelajari.

\section{KESIMPULAN}

Berdasarkan hasil penelitian dan pembahasan menunjukkan bahwa analisis motivasi siswa dalam mengerjakan tugas rumah di SMA Al-Mannan tidak termotivasi, ini dilihat dari indikator pertama mau mencoba dan mencoba meskipun berulangkali gagal bahwa siswa acuh dengan adanya pemberian PR, apalagi dengan adanya remedial guna memperbaiki nilai mereka yang kurang, siswa pun hanya sebagian kecilnya saja yang semangat untuk bertanya pada guru terkait tugas-tugas ataupun PR. indikator ke-2 lebih awal mengerjakan tugas atau PR siswa jarang sekali mengerjakan PR siswa mengerjakan PR hanya pada saat memiliki waktu yang luang. Indikator ke-3 yakni aktif pada saat pembelajaran siswa kurang aktif dalam merespon guru sehingga kurang sekali terjadi adanya feedback antara siswa dan guru di dalam kelas, siswa kurang memperhatikan dan kurang fokus karena terkadang siswa kecapean yang membuat siswa mudah mengantuk sehingga tidak jarang catatan milik mereka tidak lengkap dan lupa 
akan adanya PR. Indikator ke-4 tepat waktu dalam mengumpulkan tugas atau PR, siswa kurang disiplin dalam mengumpulkan tugas karena siswa mendahulukan tugas dari pondok. Faktor penghambat motivasi siswa dalam mengerjakan tugas rumah (PR) adalah kegiatan pondok yang padat sehingga menyulitkan siswa dalam membagi waktu dengan mengerjakan tugas-tugas yang diberikan di dalam sekolah dan juga karena kegiatan ini siswa sering merasa malas karena kecapean yang di akibatkan kurangnya jam istirahat dimana kegiatan pondok ini menjadi faktor penghambat paling umum menurut siswa selain itu media pembelajaran di sekolah yang minim juga sangat berpengaruh bagi keaktifan siswa karena menjadi sumber belajar, tidak adanya reward dan punishman, siswa cenderung bosan dengan metode ceramah yang lebih banyak digunakan guru dan siswa kurang percaya diri di dalam kelas saat berinteraksi dengan guru saat proses pembelajaran sedang berlangsung.

\section{UCAPAN TERIMA KASIH}

Ucapan terima kasih yang sebesar-besarnya kami ucapkan kepada Dekan Fakultas FKIP Universitas Madako Tolitoli, Ketua Prodi Teknologi Pendidikan Universitas Madako Tolitoli, Kepala Sekolah dan segenap Dewan Guru serta siswa- siswi SMA Al-Mannan Tolitoli dan seluruh pihak yang telah terlibat dan berperan dalam penyusunan serta penyelesaian penelitian dengan judul "Analisis Motivasi Siswa dalam Mengerjakan Tugas Rumah di SMA Al-Mannan Tolitoli”. Tanpa peran dan bantuan pihak-pihak yang telah terlibat tentunya penelitian ini tidak akan terlaksana sebagaimana mestinya.

\section{REFERENSI}

Amin, M. (2019). Peran Guru Sebagai Fasilitator Dalam Meningkatkan Motivasi Belajar Siswa Pada Pembelajaran Pendidikan Agama Islam Kelas XI di SMA Al-Mannan Tolitoli. Universitas Madako Tolitoli.

Andriani, R. (2019). Motivasi belajar sebagai determinan hasil belajar siswa ( Learning motivation as determinant student learning outcomes ). 4(1), 80-86. https://doi.org/10.17509/jpm.v4i1.14958

Awe, E. Y., \& Benge, K. (2017). Hubungan Antara Minat Dan Motivasi Belajar Dengan Hasil Belajar Ipa Pada Siswa Sd. Journal of Education Technology, 1(4), 231. https://doi.org/10.23887/jet.v1i4.12859

Damayanti, M. (2017). Pengaruh Pemberian Tugas Terstruktur dengan Umpan Balik Individual Terhadap Hasil Belajar Siswa. Saintifik, 2(1), 46-53. https://doi.org/10.31605/saintifik.v2i1.95

Darmawan, H., Kartika, E., Pendidikan Fisika, P., PGRI Pontianak, I., \& Ampera No, J. (2017). Pengaruh Pemberian Direct Corrective Feedback Pada Pekerjaan Rumah Terhadap Hasil Belajar Siswa. Jurnal Pendidikan Informatika Dan Sains, 6(1), 1-7. http://www.journal.ikippgriptk.ac.id/index.php/saintek/article/view/482

Emda, A. (2018). Kedudukan Motivasi Belajar Siswa Dalam Pembelajaran. Lantanida Journal, 5(2), 172. https://doi.org/10.22373/lj.v5i2.2838 
Ernata, Y. (2017). Analisis Motivasi Belajar Peserta Didik Melalui Pemberian Reward Dan Punishment Di Sdn Ngaringan 05 Kec.Gandusari Kab.Blitar. Jurnal Pemikiran Dan Pengembangan Sekolah Dasar (JP2SD), 5(2), 781. https://doi.org/10.22219/jp2sd.vol5.no2.781-790

Iskandar, D. (2018). Implementasi Kompetensi Profesional Guru Dalam Meningkatkan Motivasi Belajar Peserta Didik. Journal of Management Review, 2(3), 261. https://doi.org/10.25157/jmr.v2i3.1804

Iv, K., \& Gondosuli, S. D. N. I. (2020). Analisis bentuk kedisiplinan siswa dalam mengikuti kegiatan belajar dengan motivasi belajar siswa kelas iv sdn i gondosuli gondang. 5, 318-329. https://doi.org/10.29407/jpdn.v5i2.13554

Murapi, I., Yogha, F., Dwiana, S., Universitas, A., \& Mataram, B. (2020). Pengaruh Pemberian Tugas Rumah Terhadap Hasil Belajar Siswa. 1(2), 1-10.

Penelitian, J., \& Matematika, P. (2020). Pengaruh Motivasi dan Minat Belajar Siswa Terhadap Prestasi Belajar Matematika Selama Study at Home. 4(2).

Prihatini, M. (2018). Penerapan Model Pembelajaran Pemberian Tugas Rumah Untuk Meningkatkan Hasil Belajar PKn Pada Sisswa Kelas VII-B SMP Negeri 3 Tapung. Jurnal Madania, 8(1), 53-66. Saragih, G. B. A., Palobo, M., \& Sianturi, M. (2019). Analisis Faktor-Faktor Yang Mempengaruhi Siswa Dalam Mengerjakan Pekerjaan Rumah Matematika Siswa Madrasah Aliyah Al-Munawwaroh Merauke Tahun Akademik 2017/2018. Musamus Journal of Mathematics Education, 1(2), 62-73. https://doi.org/10.35724/mjme.v1i2.1371

Sari, N., \& Sunarno, W. (2018). Sekolah Menengah Atas The Analysis Of Students Learning Motivation On Physics Learn- Ing In Senior Secondary SchooL. 3, 17-32.

Sitti, S. (2015). Upaya Guru Dalam Meningkatkan Motivasi Belajar Siswa. Jurnal Promosi, 3(1), $73-$ 82. http://dx.doi.org/10.24127/ja.v3i1.144

Sugiyono. (2015). Metode Penelitian Pendidikan. Bandung: CV Alfabeta.

Tuti Rahmah (2020). Pengaruh Pekerjaan Rumah (PR) Terhadap Prestasi Belajar Siswa. Jurnal Prosiding Seminar Nasional 2020.Surabaya. Universitas Jabal Ghafur.

Widyajayanti. (2018). Analisis Intensitas Pemberian Pekerjaan Rumah (PR) Untuk Meningkatkan Hasil Belajar Matematika. Prosiding Seminar Nasional Pendidikan Matematika Etnomatnesia 2018 769-774. Yogyakarta: Universitas Negeri Yogyakarta

Yuliani, N. F. (2013). Hubungan Antara Lingkungan Sosial Dengan Motivasi Belajar Santri Di Pesantren Madinatul Ilmi Islamiyah. Jurnal Spektrum Pendidikan Luar Sekolah, 1(2), 49-62. http://ejournal.unp.ac.id/index.php/pnfi/article/view/2428/2040

Zainal, A. (2018). Hubungan Motivasi Belajar Dengan Hasil Belajar Siswa. Inovasi Pendidikan Dan Pembelajaran Sekolah Dasar, $2(2)$, 21-29. https://doi.org/https://doi.org/10.24036/jippsd.v2i2.102701 